\title{
Tobacco Cancer : A Review
}

\author{
Amol A Patil ${ }^{1 *}$, Manohar D. Kengar ${ }^{1}$, Suhas A. Mane ${ }^{2}$, Sujit A.Waghmare ${ }^{1}$ \\ ${ }^{1}$ Department of Pharmaceutical Chemistry, Nootan College of Pharmacy, Kavtemahnkal, Maharashtra, India \\ ${ }^{2}$ Department of Pharmaceutical Quality Assurance Ashokrao mane college of Pharmacy, Pethvadgaon, \\ Maharashtra, India \\ Corresponding Author E-mail:- : amolpatilszr@gmail.com
}

\section{ABSTRACT}

Tobacco smoke is the cancerous back-up that has made the most important and successful efforts to reduce the incidence of cancer in human history. An important milestone of these efforts was the light published by Cancer Research by collaborators and colleagues, who showed the ability of tobacco to create tumors in the tissues. In this study, cancer and technological pandemics provided an effective link to cancer. It is our ethical responsibility to translate our success in reducing lung cancer worldwide, reducing the 1.25 billion people who smoke in the United State. There are huge number of herbal medicines described in Ayurvedic and other alternative traditional medicines whose popularity and use in uplifting the general health of common people is still not so efficient because of several reasons. The tobacco plant, Nicotiana tabaccum, has probably been responsible for more deaths than any other herb. Present, irrational tobacco use is causing over 3 million deaths a year worldwide, and if current trends continue the annual mortality will exceed 10 million by around 2030 .

Keywords : Nicotiana Tabaccum, Cancer, Herbal Medicines, Nicotine, Lung Cancer.

\section{INTRODUCTION}

Tobacco smoking (TS) is one of the causes of the incidence and mortality of cancer in the world. ${ }^{[1]}$ It is responsible for about $25 \%$ of all cancers in men, $4 \%$ of all cancers in women and about $16 \%$ of all cancers in both sexes in most developed countries and $10 \%$ in less developed countries. ${ }^{[2]}$ In the United States, approximately $40 \%$ of the cancers diagnosed is related to tobacco consumption . ${ }^{[3]}$ According to recent research evidence, tobacco causes a lot of cases of lung cancer ${ }^{[4]}$ It is the leading cause of cancers of oral and throat, vocal cords, esophagus, stomach, kidneys, pancreas, liver, bladder, cervix, colon and rectum, and types of leukemia ${ }^{[5,6,7,8]}$ According to the Center for Cancer Prevention (CDC), tobacco-related cancers have been diagnosed between 2008 and 2013 for some 660000 people in the United States, but 343,000 of these people have died ${ }^{[9]}$ The subsequent studies in different animal species complicated the early studies on tobacco-induced cancers. While the original results of Wynder and colleagues were confirmed in many laboratories, some additional results were unexpected. For example, there is no single carcinogen in tobacco smoke . ${ }^{[10]}$ Carcinogens in chemical cigarette smoke that have been shown to cause cancer in at the least one animal species include 4-methylnitrosoamino-1-(3-pyridyl)-1-butapone (NNK), N-nitrosonornicotine (NNN), polycyclic aromatic hydrocarbons (PAH), radon, and formaldehyde. ${ }^{[11]}$

Known carcinogens, including acrolein, acetaldehyde, 1,3 butadiene, and benzene are also present in cigarette smoke, ${ }^{[12]}$ although they have not yet been conclusively shown to cause lung cancer. In the more than 7,000 compounds inhaled during smoking, 72 have thus far been identified as carcinogenic by the 
International Agency for Research on Cancer . ${ }^{[13]}$ The original goal of removing carcinogens from cigarettes was, thus, unrealistic; cigarettes cannot be sanitized.

There are huge number of herbal medicines described in Ayurvedic and other alternative traditional medicines whose popularity and use in uplifting the general health of common people is still not so efficient because of several reasons. The tobacco plant, Nicotiana tabaccum, has probably been responsible for more deaths than any other herb.

The current and unpleasant use of tobacco is expected to cause more than 3 lakh deaths worldwide and if the current trend continues, then the annual mortality rate by 2030 will be over 10 million. [14, 15] before the Civil War, the history of tobacco use has not been documented. A review of the publications on the subject shows that the long period of this plant was used by a member of the medical profession. For the tribes of the United States, traditional tobacco plants were used thousands of years ago for spiritual, formal and medicinal purposes. ${ }^{[16]}$

\section{Aims \& Objectives}

This systematic review was conducted with an objective to search and explore the traditional medicinal usage of the plant Nicotiana tabacum in different countries. Tobacco is consumed in many forms and through a number of different methods and Origin \& Distribution. Tobacco Uses in Ayurveda and Traditional Medicinal Usage. Patient Characteristics, Environmental Factors,and Lung Cancer.

Tobacco is a product prepared from the leaves of the tobacco plant by curing them. The plant is part of the genus Nicotiana and of the Solanaceae (nightshade) family. While more than 70 species of tobacco are known, the chief Commercial crop is $N$. tabacum. The more potent variant $N$. rustica is also used around the world.

\section{METHODS AND MATERIAL}

Tobacco

Tobacco flakes, sliced from pressed plugs

Product name: Tobacco

Source plant(s): Nicotiana

Part(s) of plant: Leaf

Geographic origin: The Americas

Active ingredients: Nicotine, harmine

Uses : Recreational

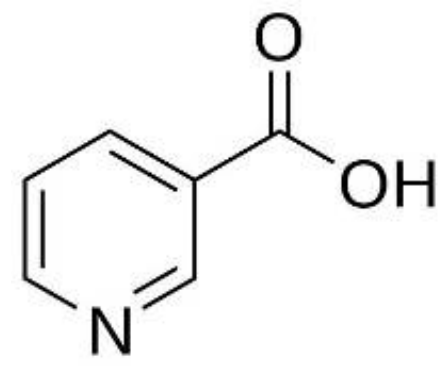

Figure 1. Nicotinic acid

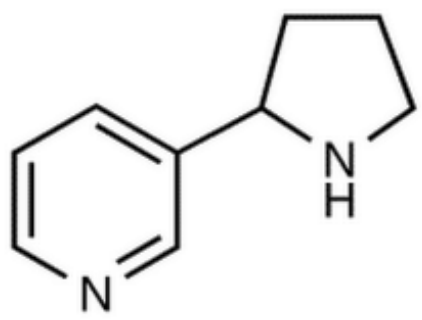

Figure 2. Nornicotine

Tobacco contains the alkaloid nicotine, which is a stimulant, and harmala alkaloids ${ }^{[17]}$ Dried tobacco leaves are mainly used for smoking in cigarettes, cigars, pipe tobacco, and flavored shisha tobacco. They can also be consumed as snuff, chewing tobacco, dipping tobacco and snus.Tobacco use is a risk factor for many diseases, especially those affecting the Basma tobacco leaves drying in the sun at Pomak village in Xanthi, Greece heart, liver, and lungs, as well as many cancers. In 2008, the World Health Organization named tobacco as the world's single greatest preventable cause of death. ${ }^{[18]}$ 


\section{Common Consumption}

Tobacco is consumed in many forms and through a number of different methods.Some examples are:

Beedi are thin, often flavored cigarettes from India made of tobacco wrapped in a tendu leaf, and secured with coloured thread at one end.

Tobacco Chewing is the oldest way to use tobacco leaves. They are used verbally, in two forms: sweet strips or in a lighter format. While using long, sweet throat, the tobacco is slightly clothed and bundled in the ball. While using the bottom of tobacco, at the lower level, gum and tooth can be kept in small quantities, where it is compacted slowly, thus it can often be said to dip tobacco.

Cigarettes are dried and acne is packed with tight tobacco bundles, which can be removed in the mouth of smokers who smoke them. Cigarettes are a product created by smoking and it is made from most of the tobacco pages and creates tobacco reconstructed tobacco and is often combined with other ingredients and brought in paper cylinders.

Creamy snuff is tobacco paste, consisting of tobacco, glycerin, spearmint, menthol, and camphor, clove oil, and sold in a toothpaste tube. It is marketed mainly to women in India, which is known by the brand names Ipco (made by Asha Industries), Denobac, Tona, and Ganesh. It is locally known as mishri in some parts of Maharashtra.

Dipping tobaco is a type of non-smoker tobacco. Dip is sometimes referred to as "chewing", and that is why it confuses chewing tobacco, which involves a lot of products. A small piece of dip is 'pinched' out of tin and put between lower or upper lip balm and mutton. Some brands with snacks are divided into small, porous pouches for less leakage.

Gutka creates crispy crushed betel nut, tobacco, and sweet or savory flavorings. It is manufactured in India and exported to some other countries. Gentle stimulants, they are sold in small, personalized packets in India
Heat-not-burn tobacco products are heat rather than burn tobacco to generate an aerosol that contains nicotine.

Hookah is a single- or multistemmed (often glassbased) water pipe for smoking. They Hookahs were first used in India and Persia; ${ }^{19]}$ the hookah has gained immense popularity, especially in the Middle East. A hookah operates by water filtration and indirect heat. It can be used for smoking herbal fruits or moassel, a mixture of tobacco, flavoring, and honey or glycerin.

Kreteks are cigarettes made with a complex blend of tobacco, cloves, and a flavoring "sauce". They were first introduced in the 1880s in Kudus, Java, to deliver the medicinal eugenol of cloves to the lungs.

Roll-your-own, often called 'rollies' or 'roll-ups', are relatively popular in some European countries. These are Prepared from loose tobacco, cigarette papers, and filters all bought separately. They usually cheaper to make.

A tobacco pipe typically consists of a small chamber (the bowl) for the combustion of the tobacco to be smoked and a thin stem (shank) that ends in a mouthpiece (the bit). Shredded pieces of tobacco are placed into the chamber and ignited.

Tobacco edibles, often in the form of an infusion or a spice, have gained popularity in recent years.

Topical tobacco paste is sometimes used as a treatment for fire ant, wasp, hornet, scorpion, and bee stings. ${ }^{[20]}$ An amount equivalent to the contents of a cigarette is mashed in a cup with about a half a teaspoon of water to make a paste that is then applied to the affected area.

Tobacco water is a traditional organic pesticide that is used in domestic gardening. Tobacco dust can be used in the same way. It is made by boiling tobacco for water, or for longer time by drinking tobacco water. After cooling, the mixture can be used as a spray or 'painted' on the leaves of the garden plants, where it kills the insects. However, the use of tobacco as a 
pesticide in organic production is prohibited from the national biological program of USDA. ${ }^{[21]}$

\section{Origin \& Distribution}

The written history of tobacco begins in the year 1492 when Christopher Columbus discovered American Indians treating their ills with leaves of an herb which he had never seen before. After that in 1536, European travelers to the New World carried home a considerable body of medical knowledge concerning the plant, acquired from Native American laymen, medicine men, and physicians in many parts of the Western Hemisphere. This knowledge wasquickly spread by word of mouth and by books published and circulated throughout Western Europe. The result was that Western European physicians adopted tobacco as medicine. Natural occurrence of nicotiana is restricted to the American continent, Australia and the South Pacific. The majorities are confined to South America and this, with other geographical evidence suggests a South American origin for this genus. Nicotiana tabacum originated from the borders of Argentina \& Bolivia. It has been cultivated in pre Columbian times in the West Indies, Mexico, and Central America. Now it is cultivated crop worldwide. ${ }^{[22,23]}$ Around $0.25 \%$ of India's cultivated land is used for tobacco production. [24] Andhra Pradesh, Gujarat, Karnataka and UP together account for over $90 \%$ of the total tobacco production in the country. ${ }^{[25]}$ It is also grown in Bihar, Maharashtra, Orissa, Tamil Nadu, and West Bengal.

\section{Varities of tobacco}

The genus Tobacco includes more than 70 species with variable biological activities and most of them are indigenous to America. ${ }^{[26]}$ Most are indigenous to America. Nicotiana tabacum, the plant now raised for commercial tobacco production, is probably of South American origin and Nicotiana rustica, the other major species which was carried around the world, came from North America. Both species are found distributed from Florida to New Mexico, to Massachusetts, New York, Southern Ontario and Minnesota. N. tabacum has a uniquely high proportion of alkaloids occurring as nicotine and is considered to have survived as a species by man's protection. Apart from this there are other varieties cultivated commonly like N. affinis; N. rustica; N. Sanderae; N. alata grandiflora; N. acuminata; N. Bigelovii (Indian Tobacco); N. longiflora; N. noctiflora; $\mathrm{N}$.

suaveolens; N. sylvestris; N. Tabacum; N.wigandioides etc. ${ }^{[27]}$

\section{Tobacco Uses in Ayurveda}

The Plant Tobacco was not included in Ayurveda in the classics of Vedic and Samhita period. It was included by the sages of later era during medieval period after evaluating the medicinal properties of this plant. The first references of tobacco are found in certain Nighantus of 19th Century. In Ayurveda texts Tobacco is referred as Tamakhu, Ksharapatra, Krimighni, Dhumrapatrika , [28] Vajrabhringi, [29] Bahubeeja, Bahuphala, Sukshmabeeja, Deerghaka. ${ }^{[30]}$

The Ayurvedic pharmacology indicates that it is Ushna (hot), Tikshna (Sharp), Sara (stimulates peristaltic movements) and increases Pitta (Digestive fire / Bile juice/ enzymatic metabolisms). It is a drug of choice in Bastivishodhana (Urinary track disorders and diseases related with urinary bladder). It is bitter and pungent in taste.

\section{RESULTS AND DISCUSSION}

\section{Traditional Medicinal Usage}

\section{Argentina}

Leaves are smoked by adults during healing rituals. ${ }^{[31]}$ If baby suffers stomach problems, then aromatic herbs 
together with black wool, tobacco and "chuspa e cacu" (the nest of Cacicus chrysopterus; Icteridae, Aves) should be fumigated around his craddle and his anus. Tobacco is used to treat distemper in veterinary with milk and cooking oil. Lemon, onion and milled tobacco with white soap in warm water is used to treat scabies in animals. It is applied in snake bites with milk and oil, or fried in oil and Tanacetum parthenium . [32]

\section{Brazil}

Dried leaves are used as an insecticide. The Tukanoan peoples of the Vaupes rub a decoction of the leaves over sprains \& bruises. The leaf juice is taken orally to induce vomiting \& narcosis. ${ }^{[33]}$ Pedro Alvarez Cabral in Brazil reported using the herb for ulcerated abscesses, fistulas, sores, inveterate polyps and many other ailments . ${ }^{[34]}$

\section{China}

The traditional (Lop Nor region) use of Apocynum venetum with tobacco as an agent to detoxify nicotine. ${ }^{[35]}$

\section{Colombia}

Poultice prepared from Fresh leaves is used over boils \& infected wounds. Crushed leaves with oil from palms used to prevent baldness . ${ }^{[36]}$

\section{Cuba}

Extract of the leaf is taken orally to treat dysmenorrhea . ${ }^{[37]}$

\section{East Africa}

Dried leaves of Nicotiana tabacum an Securinega virosa are mixed in a paste \& used externally to destroy worms in sores . ${ }^{[38]}$

\section{Fiji}

Fresh root is taken orally for Asthama \& indigestion.

Fresh root juice is applied opthamically as a drop for bloodshot eyes. Seeds are taken orally for rheumatism and to treat hoarseness . ${ }^{[39]}$

\section{Guatemala}

Leaves are applied externally for myasis, headache and wounds. ${ }^{[00]}$ Hot water extract of dried leaf are applied externally for ringworms, wounds, ulcers, bruises sores \& stomatitis . ${ }^{[41]}$ The leaf is taken orally for kidney disease. A mixture of leaf with menthol is applied externally in children for cough. ${ }^{[42]}$

\section{Haiti}

Decoction of dried leaf is taken orally for bronchitis \& pneumonia.$^{[43]}$

\section{India}

Juice of Securinega leucopyrus is mixed with the dried leaf of tobacco and applied externally for parasites . Fresh leaf is mixed with corncob or Amorphophallaus paenoifolium to treat asthma. ${ }^{[4]}$ Powdered tobacco, or masheri, is rubbed on the teeth for this purpose and tobacco toothpaste is marketed commercially. ${ }^{[45]}$ The leaves of the tobacco plant have been used in traditional Indian medicine as a sedative, antispasmodic, and vermifuge. They are also considered antiseptic,emetic and narcotic. A decoction of leaves is applied locally for muscle relaxation associated with joint dislocation. It is also used to relieve pain and swelling associated with rheumatic conditions. Tobacco is also utilized traditionally to treat strangulated hernia, orchitis, and skin diseases. The tribal inhabitants of Surguna district of Madhya Pradesh state apply warmed leaves on testis to treat hydrocele. Even the oil extracted from the leaves is used in the treatment of arthralgia, gout and lumbago.

\section{Nicaragua}

Leaves are chewed for tooth ache . It is also applied externally for pain, stings \& skin rashes. ${ }^{[46]}$

\section{Nigeria}

Hot water extract of the fresh leaf is taken orally as a sedative ${ }^{[47]}$ The sundried leaves are ground to smooth powder and used as a snuff or put on the tongue as a stimulant. For the treatment of convulsions, leaves are crushed and juice is collected which is used as a bath in water. ${ }^{[48]}$

\section{Turkey}

Powdered leaf is applied externally for wounds. ${ }^{[49]}$

\section{United States}


Extract of the plant is taken orally to treat tiredness, ward off diseases, \& quiet fear. ${ }^{[50]}$ Tobacco, probably mixed with lime or chalk, appears to have been used in these Native American populations as toothpaste to whiten the teeth, as observed by Nino and Guerra in 1500 and by Vespucci at about the same time in Venezuela. ${ }^{[51]}$

\section{Patient Characteristics,Environmental Factors,and Lung Cancer}

Certain patient characteristics have consistently shown an impact on lung cancer outcomes. For example, lung cancer is a disease of the elderly, although advancing age was not a prognostic factor for survival but high scores on the Charlson Co morbidity Index (CCI) were a factor. Taken together, toxicity, age and high CCI scores were significant predictors. ${ }^{[52]}$ The incidence of lung cancer is higher among men (34\%) as compared to women (13.5\%). The age-standardized ratio for cancer incidence is $33.81 \%$, and for mortality is $29.2 \%$ in men alone. ${ }^{[53]}$

In the past, the incidence was lower in females, but worldwide it is now the fourth most frequent cancer in women (516,000 cases; $8.5 \%$ of all cancers) and the second most common cause of cancer deaths $(427,000$ deaths; $12.8 \%$ of the total). ${ }^{[54]}$ The highest incidence rate in women is observed in North America, where lung cancer is now the second most frequent cancer in women. This is attributed to smoking. It is the lowest in central Africa, where it is the 15th most frequent cancer in women. As one in 5 women who develop lung cancer is a never-smoker, it remains a mystery as to what exactly causes their cancer.Lung cancer in never-smokers is proposed to be due to multiple risk factors, including genetic predisposition—although this is exceedingly rare (1\% with $>3$ affected relatives). Genetics mutations remain an underlying cause as we do encounter lung cancer at a relatively earlier age when it runs in families.
Among the first studies revealing a genetic link was one conducted over 40 years ago by Tokuhata et al.[55] The study revealed that never smokers with lung cancer were $40 \%$ more likely than never-smoking controls to report a first degree relative with lung cancer. Women were more likely to report such a family history and $10-15 \%$ had at least one firstdegree relative with the disease. In a landmark hormonal therapy study of 16,608 post-menopausal females, the risk of developing non-small-cell lung cancer (NSCLC) was not significant $(P 0.21)$ in the experimental arm (treatment with oestrogen / medroxyprogesterone acetate) compared to the placebo group; however, after a follow-up of 5 years a divergence emerged, with more lung cancer diagnoses in the treatment arm. In addition, these females had poorly differentiated tumors and a higher incidence of metastatic disease. There was a $30 \%$ increase in cardiovascular events, a $26 \%$ increase in breast cancer, and a $40 \%$ increase in cerebral vascular accidents (CVAs) compared to the placebo group. The hormonal treatment of postmenopausal women did not increase incidence of lung cancer,yet, it increased the lung cancer specific mortality, in particular deaths from NSCLC. ${ }^{[56]}$

Certain occupations are also associated with a higher risk of developing lung cancer (e.g. miners, asbestos workers, glass manufacturers, painters, printers and masonry workers). Many occupational substances carry a substantial risk, e.g. diesel and welding fumes, motor exhaust, natural fibers (asbestos, silica, wood, or coal dust), radon, reactive chemicals (mustard gas, vinyl chloride) and solvents (benzene, toluene). Aden carcinoma subtypes are also associated with sub pleural scars secondary to chronic inflammation (e.g. old infarcts, healed granuloma or pneumonitis and post-traumatic scars). ${ }^{[57]}$ C-reactive protein (CRP) levels were documented to be higher in NSCLC in a study suggestive of an etiologic role of chronic inflammation in NSCLC carcinogenesis. Females with 
lung cancer tend to live longer compared to men because of diagnosis at a younger age, possibly diagnosis at an earlier stage, having adenocarcinoma more frequently, and perhaps due to inherent longevity. It is also possible that their superior survival in lung cancer is due to differences in nicotine metabolism, cytochrome $\mathrm{P}-450$ enzymes and lifestyle. ${ }^{[58,59,60]}$

\section{IV.CONCLUSION}

Tobacco is a plant with an extraordinary history of use. It commenced with a history of sacred worship in the Native American Pipe ritual, when smoking tobacco would support and clear the mind as the smoke was believed to carry one's prayers to the Great Spirit. In addition, it had a wide variety of uses for physical complaints, such as venomous bites and stings, internal and external parasites, and the symptomatic relief of pain, which justifies its wide use and appreciation by traditional practitioners all over the world. As we release our addiction to, and dependence on smoking tobacco, one should not forget its many practical folklore traditional medicinal uses. Smoking has a multidimensional impact on lung cancer. It remains the most consistent causative agent for developing the disease and carries a definitive prognostic and predictive value. Aden carcinoma is more common in never smokers.

and females. The rates for EGFR and EML4 ALK mutations are higher in never-smokers providing these individuals a chance for targeted therapy. However, TKIs are ineffective in smokers with $K$-Ras mutations. Therapy optimizations should be integral while planning therapy. There is enormous room for molecular profiling of neversmokers where carcinogenesis stays presumptive. Smoking during a course of therapy remains detrimental, and patients should be advised to discontinue it as soon as possible.

\section{REFERENCES}

[1]. For Disease CC, Prevention. 2002 Annual smoking-attributable mortality, years of potential life lost, and economic costs-united States, 1995-1999. MMWR. Morbidity and Mortality Weekly Report 51, 300-3.

[2]. Sasco AJ, Secretan MB, Straif K. 2004 Tobacco smoking and cancer: a brief review of recent epidemiological evidence. Lung Cancer (Amsterdam, Netherlands) 45, S3-9.

[3]. Statistics N. 2016 National vital statistics report.
[4]. Pope CA, Burnett RT, Turner MC, Cohen A, Krewski D, Jerrett M. 2011 Lung cancer and cardiovascular disease mortality associated with ambient air pollution and cigarette smoke: shape of the exposure-response relationships. Environmental Health Perspectives 119, 161621.

[5]. Yadav D, Lowenfels AB. 2013 The epidemiology of pancreatitis and pancreatic cancer. Gastroenterology 144, 1252-61.

[6]. Chuang SC, Lee YC, Hashibe M, Dai M, Zheng T, Boffetta P. 2010 Interaction between cigarette smoking and hepatitis $B$ and $C$ virus infection on the risk of liver cancer: a metaanalysis. Cancer Epidemiology, Biomarkers \& Prevention 19, 1261-8.

[7]. Limsui D, Vierkant RA, Tillmans LS, Wang AH, Weisenberger DJ, Laird PW. 2010 Cigarette smoking and colorectal cancer risk by molecularly defined subtypes. Journal of the National Cancer Institute 102, 1012-22.

[8]. Gandomani HS, Tarazoj AA, Salehiniya H. 2017 Cigarette: The Silent Killer in the World. Biomedical Research and Therapy 4, 1624-8.

[9]. Centers for Disease Control Prevention. Classification of Diseases, Functioning, and Disability http: https://wwwcdcgov/media/releases/2016/p1110vital-signs-cancer-tobaccohtml.206.. null

[10]. Loeb LA, Ernster VL, Warner KE, Abbotts J, Laszlo J. Smoking and lung cancer: an overview. Cancer Res 1984;46:5453-62.

[11]. In Hecht SS, Hoffmann D. Tobacco-specific nitrosamines, an important group of carcinogens in tobacco and tobacco smoke.Carcinogenesis 1988;9:875-84.

[12]. Zhang S, Balbo S, Wang M, Hecht SS. Analysis of acrolein-derived 1,N2propanodeoxyguanosine adducts in human leukocyte DNA from smokers and nonsmokers. Chem Res Toxicol 2011;24:119-24. 
[13]. Hecht SS. Research opportunities related to establishing standards for tobacco products under the Family Smoking Prevention and Tobacco Control Act. Nicotine Tob Res 2012;14:18-28.

[14]. Peto R, Lopez AD, Boreham J, Thun M, Heath C Jr, Doll R.Mortality from smoking worldwide. Br Med Bull. 1996;52(1):12-21.

[15]. Reddy KS and Gupta PC. Report on Tobacco control in India-Executive summary supported by Ministry of Health \& Family Welfare, Government of India. New Delhi. 2004.p.1-5.

[16]. http://www.tobaccofreeu.org/your_state/docum ents/NAFactshe et.pdf [Access date: 15.03.2012].

[17]. Rudgley, Richard. "Tobacco: from The Encyclopedia of Psychoactive Substances" . Biopsychiatry. Little, Brown and Company (1998). Retrieved 26 November 2017.

[18]. "WHO Report on the global tobacco epidemic, 2008 (foreword and summary)" (PDF). World Health Organization. 2008: 8."Tobacco is the single most preventable cause of death in the world today."

[19]. American Lung Association. February 2007 An Emerging Deadly Trend: Waterpipe Tobacco Use

[20]. Beverly Sparks, "Stinging and Biting Pests of People" Archived 2007-02-14 at the Wayback Machine Extension Entomologist of the University of Georgia College of Agricultural \& Environmental Sciences Cooperative Extension Service.

[21]. "Generic Materials Search | Organic Materials Review Institute" . Omri.org. Archived from the original on 2015-07-23.Retrieved 2014-10-03.

[22]. Ross IA. Medicinal Plants of the World, Vol-3, Humana Press, Totowa, New Jeersey, 2007; 272273.

[23]. Feinhandler SJ, Fleming HC, Monahan JM. PreColumbian tobaccos in the Pacific. Economic Botany. 1979; 33:213-26.
[24]. www.http://en.wikipedia.org/wiki/Cultivation of tobacco\#India [Access date: 22.04.2012]

[25]. Goyal SK, Biswal PC, Ranganathan KVK. Economic history of tobacco production in India, Institute for Studies in Industrial Development, New Delhi. 2004.p.6.

[26]. http://www.ethnoleaflets.com/leaflets/tobacco.h tm [Access date: 15.03.2012]

[27]. Knapp S, Chase MW, Clarkson JJ. Nomenclatural changes and a new sectional classification in Nicotiana (Solanaceae). Taxon. (2004); 53(1):73-82.

[28]. Shaligram VL, Nighantubhushanam S. Khemraj Krishnadas Prakashan Mumbai. 4th Edition April 2004.p.908.

[29]. Vaidya Bapalal G. Nighantu Adarsha Volume 2, Chaukhambha Bharati Academy, Varanasi, 2009.p.146.

[30]. Shastry Vaidya Laxmipati, Yogaratnakar with Vidyotini Tika, Choukhambha Sanskrit Samsthan, Varanasi, 7th Edition. 1999.p.34.

[31]. Desmarchelier C. Ritual \& Medicinal Plants of the Ese'ejas of Amazonian rainforest. Journal of Ethnopharmacology. 1996;52(1):45-1.

[32]. Martínez GJ and Luján MC. Medicinal plants used for traditional veterinary in the Sierras de Córdoba (Argentina): An ethnobotanical comparison with human medicinal uses. Journal of Ethnobiology and Ethnomedicine. 2011;7(1):23.

[33]. Hirschmann GS, De Arias AR. A survey of medicinal plants of minas gerais, Brazil. Journal of Ethnopharmacology. 1990;29(2):159-72.

[34]. http://en.wikipedia.org/wiki/Nicotiana_tabacum \#Part_used [Access date: 29.03.2012]

[35]. http://www.planetherbs.com/theory/briefhistory-and-cultureof tobacco.html[Access date: 10.03.2012]

[36]. Xie W, Zhang X, Wang T, Hu J. Botany, traditional uses, phytochemistry and pharmacology of Apocynum venetum L. 
(Luobuma): A review. Ethnopharmacol. 2012; 141(1):1-8.

[37]. Schultes RE. The healing forest: Medicinal \& Toxic Plants of the northwest Amazonia. Dioscorides Press, Portland. 1995.p.432-6.

[38]. Roig Y and Mesa JT. Plantas Medicinales, Aromaticas o Venenosas de cuba. Ministerio de Agricultura, republica de Cuba, Havana. 1945.p.872.

[39]. Vanio H. Tobacco and Cancer. Cancer Res. 1986; 46(1):444-7.

[40]. Loewenthal R, Pe'er J. Traditional methods used in the treatment of ophthalmic diseasesamong the Turkana tribe in northwest Kenya. J Ethnopharmacol. 1991; 33(3):227-9.

[41]. Ilham M. Tumor promoting activity of plants used in Malaysian traditional Medicine. Nat Prod Sci. 1995;1(1):31-32.

[42]. Viesca-Trevino C. Estudios sobre ethenobotanica anthropologia medica. Inst Mexicano para est pl Medic, Mexico.1976.p.104

[43]. Flores JS. The secretions and exudates of plants used in Mayan traditional Medicines, Journal of Herbs Spices Medicinal Plants; 1996; 4(1):53-9.

[44]. Bhattarai NK. Medical ethnobotony in the Karnali zone, Nepal; Econ Bot.1992; 46(3):25761.

[45]. Barrett B. Medicinal Plants of Nicaragua'satlantic coast; Econ Bot.1994; 48(1):8-20.

[46]. Coee FG. Ethnobotony of Garifuna of eastern Nicargua; Econ Bot.1996; 50(1):71-107.

[47]. Adesina SK. Studies on some plants used as anticonvulsants in Amerindian \& African traditional Medicine; Fitoterapia.1982; 53:14762.

[48]. Bhat RB, Adeloye AA and Etejere EO. Some Medicinal Plants of Nigeria. Journal of economic and taxonomic botany. 1985;(6)1:1615.
[49]. Tabata M. Traditional Medicine in Turkey III. Folk Medicine in east Anatolia, Van and Biltis province, Int J Pharmacog.1994;32(1) 3-12.

[50]. Hussey JS. Some useful plants of early new England. Econ Bot. 1974; 28(3):311-37.

[51]. Brookes JE. Tobacco: It's History Illustrated by The Books, Manuscripts and Drawings and Engravings in the Library of George Arents Jr.1937; 1:1507-615.

[52]. Luu DCN, Mamet R, Zornosa CC, Joyce CN, D'Amico TA, Gregory P, et al. Retrospective analyses of the impact of age on overall survival in patients with nonsmall cell lung cancer. J Clin Oncol 2012.

[53]. Jemal A, Bray F, Center MM, Ferlay J, Ward E, Forman D, et al. Global cancer statistics. CA Cancer J Clin 2011; 61:69-90.

[54]. World Health Organization International Agency for Research on Cancer. GLOBOCAN 2008. From:

[55]. http://globocan.iarc.fr/ Accessed: Nov 2012.

[56]. Tokuhata GK, Lilienfeld AM. Familial aggregation of lung cancer in humans. J Natl Cancer Inst 1963; 30:289-312.

[57]. Chlebowski RT, Schwartz A, Wakelee H, Anderson GL, Stefanick ML, Manson JE, et al. Non-small cell lung cancer and estrogen plus progestin use in postmenopausal women in the Women's Health Initiative randomized clinical trial. American Society for Clinical Oncology (ASCO) 2009; Abstr \# CRA1500.

[58]. Bobba RK, Holly JS, Loy T, Perry MC. Scar carcinoma of the lung: A historical perspective.Clin Lung Cancer 2011; 12:148-54.

[59]. The Mesothelioma Center. Asbestos-Related Lung Cancer Prognosis. From: http://www.asbestos.com/cancer/lungcancer/survival-rates.php Accessed: Nov 2012.

[60]. Kligerman S, White C. Epidemiology of lung cancer in women: Risk factors, survival, and screening. Am J Roentgenol 2011; 196:287-95. 
[61]. National Cancer Institute. SEER Cancer Statistics Review, 1975-2007. From: http://seer.cancer.gov/csr/1975_2007/ Accessed: Nov 2012.

\section{Cite this article as :}

Amol A Patil, Manohar D. Kengar, Suhas A. Mane, Sujit A.Waghmare, "Tobacco Cancer : A Review", International Journal of Scientific Research in Science and Technology (IJSRST), Online ISSN : 2395-602X, Print ISSN : 2395-6011, Volume 7 Issue 1, pp. 01-10, January-February 2020. Available at doi : https://doi.org/10.32628/IJSRST196610 Journal URL : http://ijsrst.com/IJSRST196610 